\title{
Surgical Emotions: How TV and Newspaper Coverage Furthered the Cause of Heart Transplantation in France (1968-1973)*
}

Philippe Chavot, Anne Masseran

\begin{abstract}
This paper shows the influence of media coverage for the fate of heart transplantation in France. It argues that the media's support not only reinforced the graft's medical legitimacy, but also sustained the practice by mobilizing public support. Our study focuses on two peaks in media coverage. The first took place in 1968/69, as the first grafts in the world and in France were performed. The second occurred in 1973, when surgeries resumed in France following a four-year hiatus due to the mixed results of the early operations. French transplants were then largely covered on TV and in newspapers. We examine the reasons for these peaks in coverage and the underlying rationales of the alliance between French surgeons and journalists. Cross-analysis of TV and print productions sheds light on the media devices used to enlist the general public's moral support. It shows that state television proved an effective platform for doctors, allowing for a different kind of storytelling than in newspapers.

Television studies, science popularization, organ transplantation, France, heart transplant

* This research received funding from the European Research Council (ERC) "The healthy self as body capital (BodyCapital)" project under the European Union's Horizon 2020 research and innovation programme (grant agreement No 694817). We would like to thank the INA and its staff for making the archive descriptions and videos available to social scientists. This paper was translated from French by Jean-Yves Bart, with support from the Maison Interuniversitaire des Sciences de l'Homme d'Alsace (MISHA) and the Excellence Initiative of the University of Strasbourg.
\end{abstract}

Philippe Chavot, Laboratoire Interuniversitaire des Sciences de l'Education et de la Communication (LISEC - Université de Strasbourg), philippe.chavot@unistra.fr

Anne Masseran, Centre de Recherche sur les Médiations (CREM - Université de Lorraine) et Université de Strasbourg, masseran@unistra.fr 


\section{Introduction}

In November 1965, the newspaper Le Monde (LM) announced that over 250 kidney transplants had been successfully performed since the first "French [...] victory report" in 1959 (LM 24-11-1965). ${ }^{1}$ In 1961, the first kidney transplant between cousins had demonstrated the advancement in the understanding and mastery of tissue rejection, of rejection treatment and of donor-recipient compatibility. The institutionalization of the field of transplantation began with the creation of the journal Transplantation (1963) and of the scholarly society The Transplantation Society (1966). Medical specialists were hoping to be able to transplant other organs, including the heart. And at the time, several surgeons stated that they were ready to take this step. ${ }^{2}$ Heart transplantation was discussed for the first time in France in a fulllength film broadcasted in 1965 on the country's first TV channel. The film gave a detailed step-by-step account of a homograft in a dog. ${ }^{3}$ The scientist interviewed in the film contended that human heart transplantation would only be feasible once rejection mechanisms could be kept in check and ethical barriers crossed. In June 1967, Paris hosted the first international congress of The Transplantation Society, where it was concluded that it was possible to extend transplantation to the heart, among other organs. ${ }^{4}$ In an interview with French reporter Pierre Bourget, the Boston surgeon John Merrill named three remaining challenges (1ère chaine, 20h, 27-06-1967): donor-recipient pairing, controlling the rejection mechanism, preserving the graft. Technical aspects were left unmentioned but did not seem to be an obstacle: extracorporeal blood circulation was already used for open-heart surgery, and surgeons had been experimenting with transplant on dogs for years, both in the United States and in France. In November 1967, the newspaper SudOuest (SO) announced that the American surgeon Norman Shumway claimed to be ready to perform such a surgery as soon as the ideal donor was found (SO, 21-11-1967). He reported having performed nearly 200 heart transplants on dogs, with a success rate of over 60 percent. Indeed, the media covered the subject long before the first transplant was even performed; this medical first appeared to be eagerly awaited, at least in the French media that we analysed for the purposes of this paper.

1 The 1959 "victory report" refers to the first success of kidney transplant between dizygotic twins. LM article indicates that the patient led a normal life after the transplant. A television report was devoted to this transplant on 6 November 1959, Barrère 1959.

2 Nathoo 2009.

3 Barrère/Sciandra 1965.

4 Nathoo 2009. 
On 2 December 1967, the first heart transplant performed by Pr. Christiaan Barnard at Cape Town's Groote-Shurr hospital was a watershed in two respects. ${ }^{5}$ First, on a medical level: three days after the Cape Town surgery, a transplant was performed on a baby in New York by Dr. Adrian Kantrowicz. Announcements of transplants kept coming; by late 1968, nearly a hundred heart transplants had been achieved worldwide. Second, the press extensively covered the first announcements, placing heart transplantation on the media agenda, ${ }^{6}$ whereas coverage of kidney transplants remained somewhat low-key. However, many of the attempts made in 1968 across the world ended in failure: a year after the first transplant, only 14 recipients out of 96 had lived more than three months. In many countries, the initial enthusiasm gave way to doubt and criticism. Following the death of the third patient in Britain, heart transplants were discontinued in Britain for nearly ten years. ${ }^{7}$ By the summer of 1969 , only a few hospitals in the world continued to transplant hearts, including Barnard's in Cape Town and Shumway's in Palo Alto.

This research is based on a corpus of TV segments drawn from the national audiovisual archive institute (Institut National de l'Audiovisuel, INA), the repository of all French television audiovisual archives. We selected TV items that directly referred to or spoke of heart transplants. ${ }^{8}$ This corpus was complemented by an inventory of articles on heart transplantation in two newspapers: the daily newspaper of record Le Monde (LM) and the regional daily Sud Ouest (SO) over the 1966 to 1974 period. This data is drawn from the Europresse database. ${ }^{9}$ The early days of heart transplantation were marked by two peaks of media coverage (Figures 1 and 2). The first took place in 1968-1969, as the first transplants were performed in France and abroad.

5 On Barnard's first surgeries and the reactions they elicited in a variety of countries, see Cooper 2017; McRae 2006; Joubert 2018; Nathoo 2009; Danet/Medina-Doménech 2015. On the medical history of the early heart transplantations, see Cabrol et al 1986; Turina 2018; Colombo/Amirati 2011; Marion 1990; Guilmet 1997.

6 On media agenda see McCombs/Shaw 1972. The advent of the first cardiac grafts together with the first manned space journeys greatly contributed to durably install scientific and medical news in the media agenda with a strong focus on the actors of scientific achievement. On this point, see Bauer 1988.

7 Nathoo 2009.

8 We first used the key words "transplant" and "transplantation", then we isolated the segments that accounted for cardiac transplantation. Some actors - patients and surgeons - also received coverage that did not chiefly focus on transplantation. We have not integrated these items in this corpus.

9 http://www.europresse.com/fr/. We have identified the articles integrated in our corpus via the three key words: "graft", "transplantation" and "heart". 


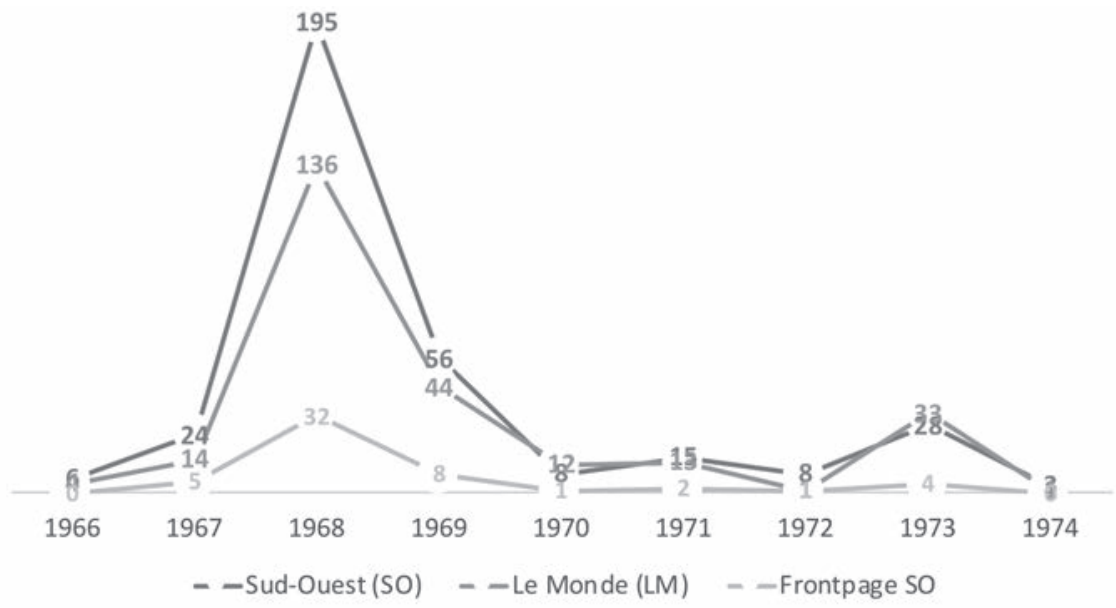

Figure 1: Number of articles on heart transplant per year (1966-1974) in the regional daily paper Sud-Ouest and the national Le Monde. Half of the collected articles were detailed articles on medical firsts that were often announced on the front page. The other half consisted of short accounts, referring to transplants achieved outside France or to the health status of grafted persons.

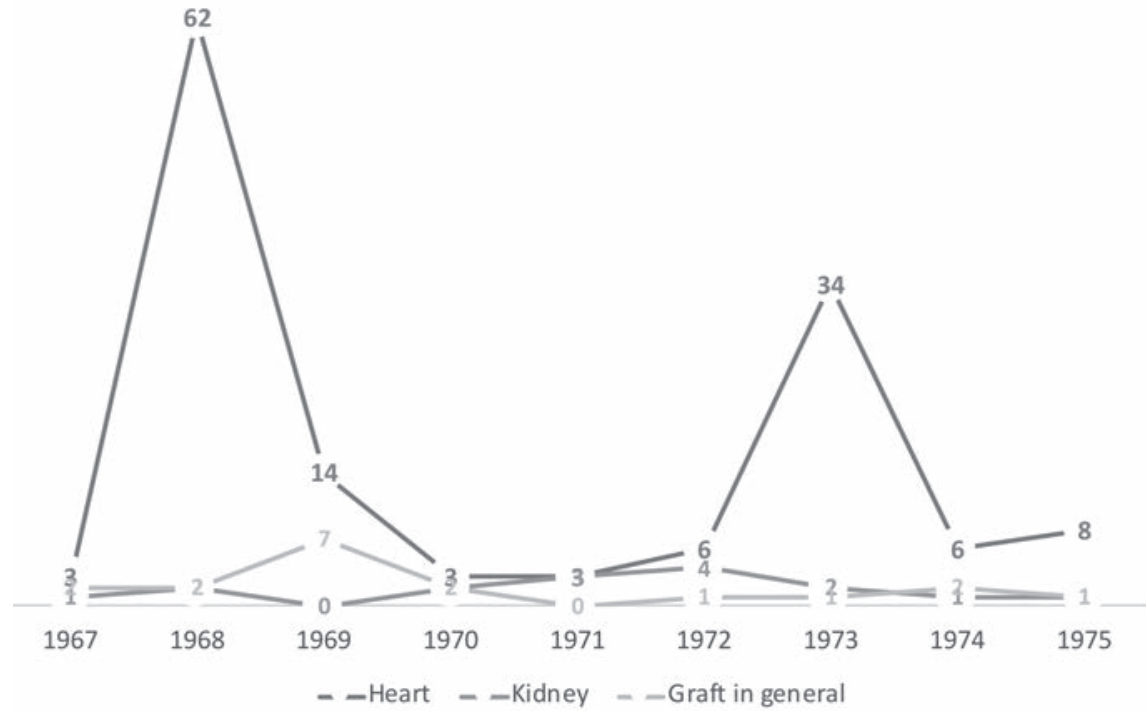

Figure 2: Number of TV segments related to heart, kidney and others organ transplants and transplantation in general per year (1967-1975) in INA descriptive records. Only a few sequences related to graft were broadcasted prior to 1967 . Heart and kidneys transplants are the most prevalent, while other organ transplants were scarcely covered in TV sequences during this period. 
Ten transplants were performed in France in 1968; only four patients survived for more than three months (three lived over a year). That year, 195 articles on the subject were published in the regional newspaper SO, 136 in LM, and 62 television clips on the subject have been catalogued by the national audiovisual archive institute. Then, in 1973, after a four-year hiatus owing to the mixed outcomes of the French transplantations, operations resumed. Six surgeries were performed during the year; three of the patients survived over a month. These transplants were the subject of 33 articles in LM and 28 in $\mathrm{SO}$, as well as $34 \mathrm{TV}$ segments. Each case was largely covered on TV and in newspapers before August, when coverage peaked before fading again.

The media coverage of heart transplants in France is a somewhat paradoxical story in itself. ${ }^{10}$ Indeed, this coverage remained intensive and positive even in 1968, when the survival rate was low. While the newspapers especially at the national level - covered both criticism and praise of heart transplantation, TV tirelessly heralded and supported France's leadership. In this article, we set out to examine how this media coverage may have contributed to developments in the medical field. Indeed, it served as means to popularize a type of surgery whose scientific and social legitimacy did not initially go uncontested. In January 1968, Shumway had already noted in a TV segment on the subject that the increase in the number of voluntary donors had been "one of the beneficial effects of the total coverage of this event by press and TV". ${ }^{11}$ French television played its part in this by producing a great narrative designed to have audiences accept and embrace heart transplantation on a moral level. ${ }^{12}$

Having characterized the distinguishing features of French TV and newspapers in the years between 1968 and 1973, we will now narrow in on the coverage of the first heart transplants of 1968 in both types of media. Emphasis will be placed on the way in which surgeons, patients and reporters addressed audiences. We will then pursue the same approach for the year 1973. Differences in coverage in both types of media between the two periods will be demonstrated. The media histories of four patients that are particularly emblematic of these periods will be studied in greater detail, giving insights into the ways in which surgeons used TV as a platform for express-

10 Studies on the links between heart transplants and the media are quite rare. Nathoo 2009 has focused mainly on British media, which delivered very different narratives from French media. Danet and Medina-Domenech 2015 have studied narratives presented in the Spanish press. Joubert 2018, for her part, has explored the way South-African medias accounted for the Cape Town's transplants. Although these contributions are particularly valuable for contrasting media treatment in different countries, no intercontextual comparison has been undertaken yet.

11 Schiller/Désiré 1968.

12 Chavot/Masseran 2012. 
ing their engagement and their feelings about transplantation. Lastly, the connections between surgeons and journalists will also be investigated.

\section{Storytelling and Heart Transplantation in Newspaper and on TV}

The newspapers and TV told the story of heart transplantation in different ways: their respective technologies and organizational forms framed their ways of reporting and developing narrative on the subject. In the 1960s and 1970s, reading the newspaper was a daily habit for a large portion of the French population. ${ }^{13}$ The data for our analysis comes from a regional daily paper and a national one, both cited above, with different editorial approaches. ${ }^{14} \mathrm{SO}$, which boasted the 'highest circulation in the Southwest' of France, ${ }^{15}$ covers Bordeaux and the surrounding region. This means it reports primarily on local news: for instance, the tenth French transplant recipient of 1968, Bernard Marion, who underwent surgery in Bordeaux, received particularly extensive coverage in SO. The paper was a staunch advocate of heart transplantation, and covered the story of each recipient. Transplantation was personalized in the process and brought into the readers' everyday lives; articles were often illustrated with photographs.

With a long and storied career under its belt, LM was, in the 1960s and 1970s, considered to be the "newspaper of record in France". ${ }^{16}$ Its editorial policy emphasized cross-checking information, reporting on international news and providing in-depth coverage. LM pursued a critical line, especially during Charles de Gaulle's presidency. During the period under study, it strived to report on scientific developments as objectively as possible. There was little room for images in LM. Doctors, however - at least at the time of the first transplants in Cape Town - found it a welcoming platform.

In the 1960s and 1970s, television became increasingly widespread in France, although it was still a relatively new object in people's homes,

13 On newspaper readership in the 1960s and 1970s, see Mouillaud/Têtu 1989; Eveno 2010.

14 On the history of the press and TV, see Jeanneney 1996. For a sociological approach to the press, see Esquenazi 2002a.

15 In 1968, SO's circulation was ca. 110,000 copies. The paper was going through an expansion phase, and would reach a circulation of 400,000 in the 1980s. Source: https://fr.wikipedia. org/wiki/Sud-Ouest (Date consulted: March 2019). On the regional press in general, see Ballarini 2008; Martin 2002.

16 In 1968, LM's circulation was 355,000 copies. The paper was also expanding, as it would circulate nearly 500,000 daily copies by the 1970 s. Source: https://fr.wikipedia.org/wiki/Le_ Monde (Date consulted: March 2019). 
wrapped in the aura of modernity. ${ }^{17}$ The French television broadcasting company (Radio télévision française - RTF) offered two channels in 1968; the third channel was created in 1972. In these early years, this was state television, heralded by the government as the leading source of information for the French people - President de Gaulle would use it to address his audience directly. ${ }^{18}$ Later, President Georges Pompidou affirmed both the power of television and the duties of TV journalists: "whether one wants it or not [...] television journalists are not exactly journalists like the others. They have additional responsibilities. Whether one wants it or not, television is considered to be the voice of France, by the French and by foreigners alike". ${ }^{19}$ Television was intent on broadcasting the greatness of France; heart transplantation, performed by French surgeons, was part of that greatness. As Pompidou noted, TV journalists had something of a special status: as they basked in the glow of the small screen, not only did they have to inform the audience, but they were also bound to refrain from overstepping certain boundaries, as the medium was considered extremely powerful.

It was thus through this small, but powerful screen that audiences often learned about heart transplantation. ${ }^{20}$ Audiovisual technology allows for a very different kind of storytelling than newspapers. The subjects are brought to life by sound and images; the audience is plunged in situ, and may be sometimes more moved, convinced or scandalized than by words or photographs alone. The recourse to live broadcasts also allowed TV viewers to experience events almost as insiders, and provided visible evidence of the reality of achievements in the field of heart transplantation. In short, viewers are called to become virtual witnesses of surgical exploits: immersed with sound and image, enjoying the live broadcasts, they are "in the place". ${ }^{21}$ Bringing these many viewers virtually into the operating or the patient's room increases the value of the evidence. The viewers see and uptake the

17 On the history of television, particularly in the 1960s and 1970s, see Bourdon 2014; VeyratMasson/Sauvage 2012.

18 In doing so, he bypassed parliament, thereby taking on a far greater role. See Esquenazi 2002b.

19 Press conference of 22 September 1972, cited in Jeanneney 1996, 284.

20 Nelkin 1987.

21 The concept of "virtual witness" was first developed by Shapin and Shaffer in their analysis of the air pump in 17th century Britain. This witnessing passed through a written diffusion of knowledge. This notion was then mobilized by Kirby who explained that cinema renewed this form in the 20th century: the immersion of the public in fiction films allows them to validate scientific knowledge for themselves. The concept has also been judiciously used in the analysis of educational films during the 20th century. It appears that the television reinforced this process in the 1960s and 1970s with the use of live broadcasts, a technical innovation that had been widely glorified by the TV presenters. See Schapin/Shaffer 2005; Kirby 2011; Bonah et al. 2018. 
reality of the success of the operation and are moved by the state and the words of the patients as if they were truly there. Likewise, as is the case for any other subject, the transformation of technologies and practices in TV influenced the form and content of transplant stories. In the 1950s and 1960s, long-format shows would allow viewers to experience medicine through filmed surgeries. Scientific explanations were provided by interviewed doctors. In the 1970s, talk shows became popular; in that form, the audience could identify with the layperson asking questions to the experts. ${ }^{22}$

Indeed, while medical advances, legislative developments, political orientations, and, obviously, the survival of patients shaped the history of transplantation in France, the media also played a key role in the development of heart transplantation during that period. Securing the moral support of a variety of audiences would effectively sustain the practice of heart transplantation in the long term. The mainstream audience's embrace - especially families - would boost organ donations; the approval of these surgeries by medical professionals would confer them legitimacy; lastly, the development of the practice hinged on public funding. All of these objectives are mentioned, alternatively by surgeons and journalists, in the corpus of television programmes that we have assembled. Herein, the media constituted a hub, where these different types of support of heart transplantation came together. We will now attempt to understand how TV in the 1960s-1970s forged storytelling around transplantation that differed markedly from the narratives and analyses presented in newspapers. ${ }^{23}$

\section{8-69: The Coverage of the First Heart Transplantations in France}

The Coverage of the Cape Town Transplants

The first heart transplant performed by Dr. Barnard on 3 December 1967 marked the beginning of media coverage on these surgeries. On 5 December, its technical and moral implications were discussed in LM. SO devoted a full page to the event. The paper profiled the donor, Denise Darval, a 24-year-old woman who had died in a car accident, ${ }^{24}$ and the recipient, 56-year-old Louis Washkansky, as well as the members of the medical team. A resident surgeon involved in the operation provided insights into the retrieval, the graft, and the precautionary measures that had been taken. Newspapers went on to give

22 Soulages 2007.

23 On the respective specificities of TV and the print press, see Lochard/Boyer 1998.

24 On coverage about the donor, see Danet/Medina-Doménech 2015. 
regular updates on the health of the "man with the grafted heart". Upon his death, 18 days after the transplant, the media specified that his lungs had failed; not his heart. The medical and media hype remained intact: for the Cape Town surgeons, the principle of heart transplant had been wholly validated (SO 22-12-1967).

Washkansky's death was an opportunity for TV to assert the scientific, therapeutic and moral legitimacy of heart transplantation. In the Panorama programme entitled "Washkansky did not die for nothing" (Washkansky $n$ 'est pas mort pour rien), broadcasted on December $22,{ }^{25}$ several French surgeons highlighted the value of this surgery. Pr. Jean Lenègre pointed out that nearly "a third of French people die from heart disease". Considering the defects that still plagued the artificial heart, transplantation appeared to be the best solution for patients with a fatal prognosis.

The coverage of the second transplant, performed in Cape Town on 2 January 1968, was absolutely identical. The name of the recipient was known before the surgery - 56-year-old Dr. Philip Blaiberg (SO 02-01-1968). On 3 January, a SO headline read: "Mrs Haupt faints as she gives away her husband's heart". The article described the stages of the surgery in detail; the principle of tissue compatibility was explained in a box inset to the article. TV aired a dozen segments and interviews on the transplant. The surgeon was presented as a heroic character. In another episode of Panorama, broadcasted ten days after the surgery and entitled "The heart: Cape Town - these doctors at the end of the world" (Le cœur: Le Cap ces médecins du bout du monde), ${ }^{26}$ donor, recipient and surgeon were woven into a single narrative. The segment begins with the interview of the donor's wife, surrounded by her family. She explains her decision to give her husband's heart to help another person. For his part, Barnard appears both as a talented and a deeply human surgeon. Science and humanity merge to form a coherent narrative whose meanings are not negotiable: heart transplantation is depicted not only as a landmark medical advance, but also as a culturally acceptable medical practice. ${ }^{27}$

25 Bourget 1967.

26 Larriaga 1968.

27 The television staging shows a positive narrative, far from the myth of Frankenstein or certain negative cinema fictions of the time accounted for by O'Neill 2006. It is a matter of showing that it is possible to give one's own organs. On this point see Chavot/Masseran 2018. 

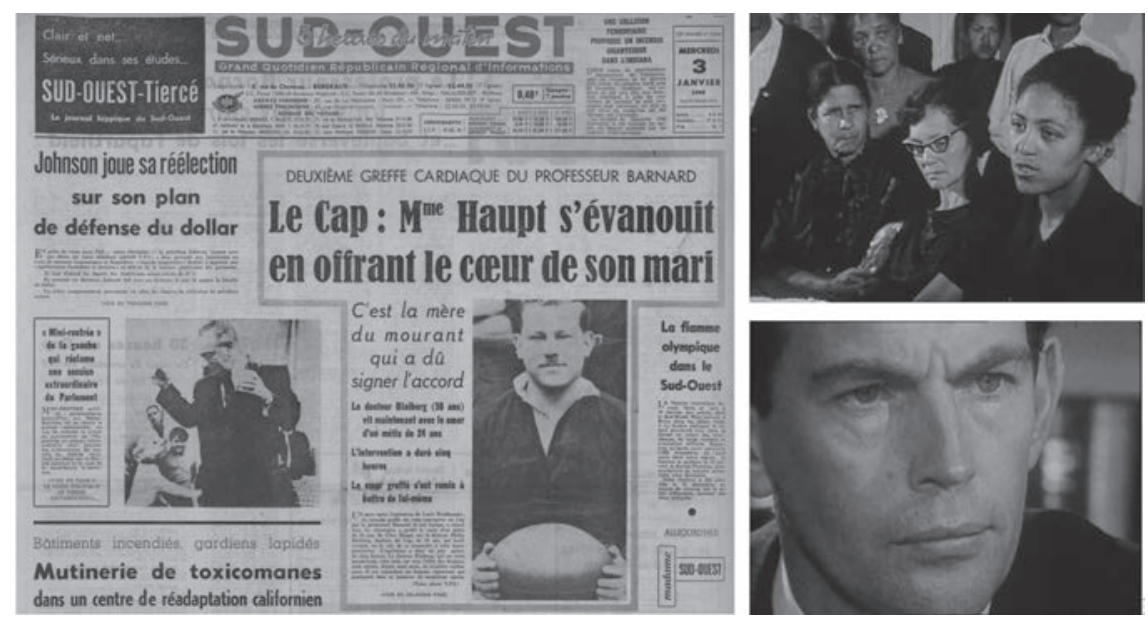

Illustration 1: Newspaper and TV reports on the second Cape Town transplant. Both insist on the part played by the family of the donor. Left, headline of SO stating "Mrs Haupt faints as she gives away her husband's heart" (SO 03-01-1968). Right, the TV report starts with the interview of the donor's wife. Then, Barnard describes the discussion he had with Mrs Haupt.

Nearly a hundred heart transplants were performed in 1968 alone. Medical first upon medical first - with the first transplant on a black person, the first in Europe, the first on a woman, etc. Yet, in early 1968, French TV was mainly interested in following Blaiberg's every move. The patient was interviewed on his hospital bed a few days after the graft. A March 1968 episode of Panorama ${ }^{28}$ showed him walking and being driven around the city with a voiceover, treatment usually reserved for heads of state. Blaiberg's longevity after the transplant - 19 months and 15 days - made him a poster boy of transplantation. ${ }^{29}$

Barnard appeared as heart transplantation's main advocate. Six days after the first surgery in Cape Town, he already claimed to be looking for a second heart. Regarding the retrieval, he argued that a "doctor should not have to artificially keep a man whose brain has suffered irreparable damage alive" (SO 29-01-1968). He supported French surgeons who were considering performing similar operations themselves, and hosted them in Cape Town in mid-January. During a visit to Paris, he announced: "the first European transplant will be performed in France" (1 ${ }^{\text {re }}$ chaine, 13h, 03-021968).

28 Bernadac 1968.

29 When Barnard was asked, during a visit in Lyon, whether performing multiple heart transplantations might be premature, he quipped back: "Ask Dr. Blaiberg what he thinks about that" (LM 27-01-1969). 
In their reports on these world firsts, newspapers and TV emphasized the same elements: the pain and generosity of the donor's loved ones, and the recovery of the recipient. Surgeons found in the media an essential platform to defend the legitimacy of heart transplantation. These features formed the core of an initial story that would be reproduced for virtually each case. However, unlike newspapers, TV gave life and faces to transplantation. Visualization generated emotion, and brought the audience closer to the operations that took place halfway across the world. Television's own status as a symbol of modernity and an object of desire reinforced the impact of this storytelling. ${ }^{30}$

\section{The ten French Grafts of 1968}

French surgeons prudently waited until April 1968 to perform their first heart transplant. An organ sharing network (LM 23-02-1968) had been set up in public hospitals, and a circular now authorized surgeons to pronounce brain death prior to retrievals (circular dated 25 April 1968, reported upon in SO 27-04-68). Unlike Barnard, the French surgeons operated discreetly, during the night of 27-28 April 1968. On the next morning, a communiqué was read on TV; a press conference was aired in the afternoon.

Television offered a wealth of detail on the circumstances of the retrieval, the graft and the treatment. The journalist Pierre Bourget conducted exclusive interviews with the main protagonists: Prs. Maurice Mercadier, Gérard Guiraudon and Christian Cabrol (1 ${ }^{\text {èr }}$ chaine, 20h, 29-04-1968). The surgeons did not disclose the donor's identity, but the media soon did. On 30 April, SO presented the donor's parents, whose son had been "impressed by the successful graft in Cape Town" (Illustration 2). A photograph of the young man was featured in the middle of the page. The trajectory of the patient, Clovis Roblain, who "kept his disease a secret in his village" was described in detail. The human angle in the newspaper's coverage contrasted with the highly technical register of the press conference. A second press conference was held the next day to announce the patient's death, the cause of which was attributed not to the graft but to exhaustion.

30 Chavot/Masseran 2019. 

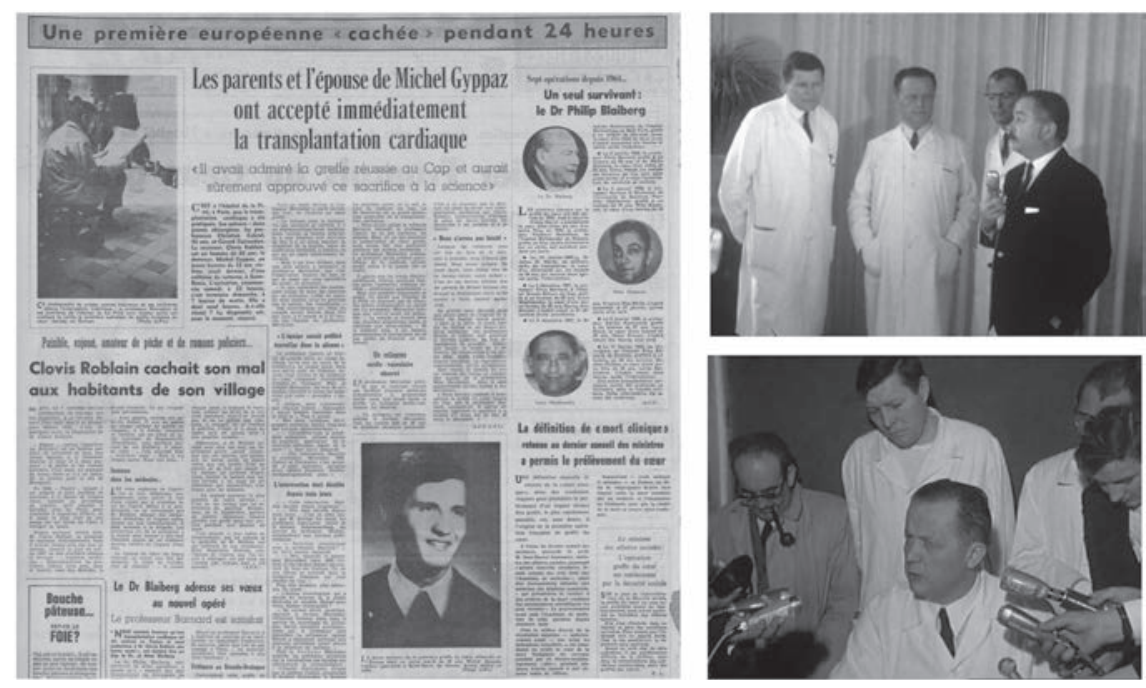

Illustration 2: Comparison of SO and TV reports on the first French heart transplant in SO and TV. SO scenarises the donor's parents and the patient while TV offer technical information through the voices of surgeons. Left, third page of SO dated 30 April 1968. Upper-Right, interview of Prs. Maurice Mercadier, Gérard Guiraudon and Christian Cabrol by Pierre Bourget (1 ${ }^{\text {ere }}$ chaine, 20h, 29-04-1968). Lower right, press conference announcing patient's death (1 chaine, 13h, 30-04-1968).

These two press conferences held at the Pitié Hospital in Paris were exceptional. Indeed, in May, the French medical association asked for the "public to be informed only by an official communiqué, in compliance with the rules of medical confidentiality", to prevent "the publicity surrounding some therapies" from becoming "detrimental to the advancement of science" (SO 0705-1968). Subsequently, surgeons had a smaller part in the coverage of the nine other transplants performed in 1968.

Despite these efforts for discretion, the media continued to publish details on the identities of recipients and donors. When the second French transplant was performed on 8 May in Montpellier, the news was only kept secret for 24 hours. A TV crew arrived the next day and interviewed the paramedic who had transported the donor to the hospital. The evening news broadcast featured an interview of the donor's wife and a colleague of the grafted patient (Illustration 3). As far as technical aspects went, the media were only given a communiqué and a tour of the operating room. The surgeons' reluctance to communicate left journalists with a bitter taste. On 10 May, a SO headline ran: "Montpellier surgical team opts for stringent discretion policy". The patient survived two days. 

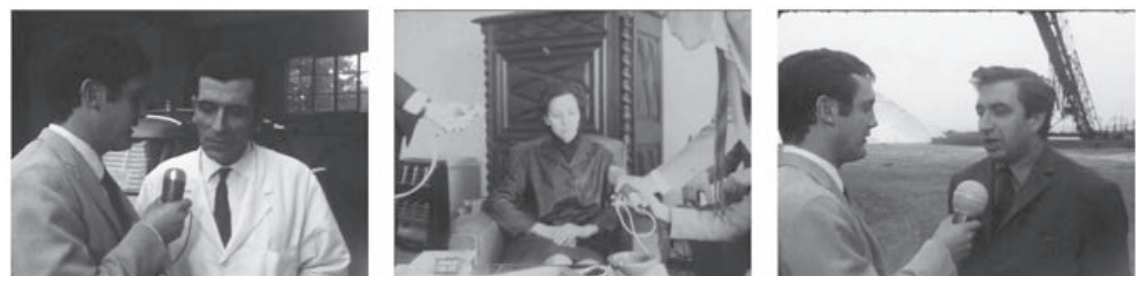

Illustration 3: Humanizing heart transplant. TV crew interviewing a paramedic, the donor's wife, and a colleague of the grafted patient (1 $1^{\text {ere }}$ chaine, 20h, 09-05-1968).

The same scenario unfolded for the third transplant, performed on 12 May by Pr. Charles Dubost at Paris's Broussais Hospital on Father Boulogne. TV reporters managed to interview one of the recipient's cousins and his sister and showed the place where he had spent his childhood. Wariness about the procedure was expressed: "I can't see the point of putting a new heart in a tired body", the Father's cousin told the interviewer (1 ̀̀re chaine, 13h, 16-051968). Other relatives praised the patients for their courage and congratulated the donors. These interviews allowed the viewers to project themselves more easily and may have fostered a positive image of transplantation in some of them.

The televisual approach was at the time incompatible with that of the French Medical Council (Conseil de l'ordre des médecins). TV journalists attempted to naturalize the connection created by the graft between individuals that initially had nothing in common, and to tell a full story that emphasized the personality of the donors and recipients. ${ }^{31}$ This led them to breach medical confidentiality and to seek out information outside of the medical field.

\section{The New Ambassadors of Heart Transplantation}

When the first surgeries took place, the surgeons appeared to opt for a very formal type of relationship with the media: they were in touch with journalists only during press conferences, and left recipients, family members and donors loved ones to take on the role of transplantation advocates. The third French transplant, performed on Father Boulogne, heralded a new approach to communication on transplantation. Unlike the first two patients, whose bodies were weakened by disease, Boulogne embodied the ideal patient. He was fairly young (56), overall healthy despite his heart condition, and most

31 SO also published narratives that involved the same protagonists that appealed to emotion, unlike LM. 
importantly, a volunteer for the graft. ${ }^{32}$ To Dubost, "both in clinical and moral terms, he met the rigorous criteria for which the indication for heart transplant should always be based" (LM 15-05-1968). Boulogne was the first French patient to survive the graft for over two weeks. On the strength of this positive outcome, Dubost claimed that technically he could perform one graft per month at the Broussais Hospital (SO 16-06-1968).

Father Boulogne greatly admired science and the work of his surgeons, and proved an eager interviewee, to the point that he gradually became the face of heart transplantation. In an interview with the magazine $L a$ vie catholique illustrée, from his sterile hospital room, Boulogne presented himself as the person who allowed "[...] doctors to bring a first experiment to completion, conducted as prudently as possible". ${ }^{33}$ He entrusted his body and soul to science in order to share his experience with the Church and society at large, and to allow each individual to develop an informed stance on transplantation. In September 1968, he was interviewed on the programme Point Contrepoint (2 ${ }^{\mathrm{èm}}$ chaine, 26-09-1968). Disputing prejudice against organ donation, he offered his personal, mechanistic vision of respect for the body: "If you open a grave after a month, you have this kind of putrid juice in which worms and maggots crawl [...]. For a loved one's organ to be of service to a new being is far more respectful". Asked about the donor, he added: "When you have a second-hand engine in your car, you're not thinking about the previous owner". The story ends with a long scene showing him walking up six flights of stairs, thereby demonstrating that his heart is working perfectly (Illustration 4).
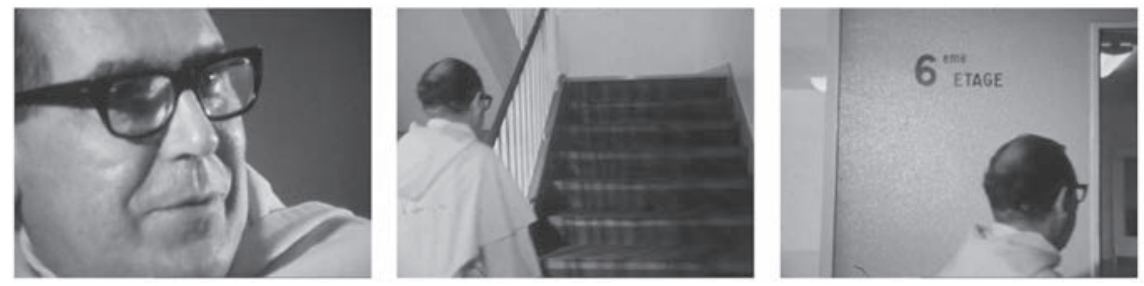

Illustration 4: The Heart transplant ambassador Father Boulogne. The interview with Father Boulogne ends with a long scene showing him walking up six flights of stairs (2 ${ }^{\text {ème }}$ chaine, 2609-1968).

32 All heart transplant patients were condemned without this last chance operation. Nonetheless they had to give their consent before the operation. Unlike other patients, Father Boulogne volunteered for such operation and asked Dubost before Barnard achieved his first heart transplant (LM, 15-05-1968).

33 This interview was partly reproduced in SO's 11 July 1968 issue. 
In November 1968, Boulogne became active in an organ donation campaign that often relied heavily on guilt as a mechanism. He claimed that "refusal to donate constitutes a crime by omission". Dubost, who found himself unable to perform more transplants due to lack of donors, supported him (SO 25-101968).

Seven grafts were performed in France between 10 November and 22 December 1968; but only two of them received media coverage. The first to be covered was performed on Emmanuel Vitria, the ninth French recipient, who underwent surgery in Marseille on 28 November. Like Boulogne, Vitria was a volunteer. In the days that followed the operation, he largely co-operated with the media and agreed to be filmed and interviewed in his sterile room, through a closed-circuit television system (1 ère $^{\text {chaine, }}$ 05-12-1968). His considerable longevity - nearly 19 years - and enthusiasm would make him a fixture in the media in the 1970s and 1980s.

The second graft that received coverage was performed on Bernard Marion in December, in Bordeaux. The regional paper SO devoted a full page to the event, weaving a narrative that connected the donor, the patient and the surgeon. SO regularly followed the new local star, covering his family's visit to the hospital, twelve days after the surgery (03-01-1969); his discharge from the sterile room (23-01-1969); and his death (05-08-1969). This patient received heavy local press coverage, but was rarely mentioned by television and national press journalists, which reflects the highly centralized nature of national media in France.

When these first transplants were performed, newspapers used essentially argumentative resources to convince readers of the value of the operations. The regional press additionally relied on emotion in its coverage of local patients, who its readers could relate to, as in the case of SO. As audiovisual media, TV was able to demonstrate the effectiveness of heart transplantation by personalizing it, as it did with the storytelling around Father Boulogne. Technological contrivances, such as interviews from sterile rooms, brought the audience even closer to the patient.

\section{Heart Transplantation in France Is Questioned}

Although not a single transplant was performed in France in 1969, the media continued to follow up on the subject. Newspapers reported on international news and developments pertaining to the French graft recipients. TV covered transplantation-related issues in a number of programmes. Two shows "Cardiac surgery at the time of transplant" (La chirurgie cardiaque à l'heure 
de la greffe) and "Restoring life" (Redonner la vie) - broadcasted in February and September $1969^{34}$ began with footage from an operation (Illustration 5). The surgeons involved - Pr. Jean-Paul Binet and Dubost - were featured as on-set guests. Viewers were presented with audiovisual evidence of the operation's technical feasibility. These included graphic images, showing an open rib cage and expert hands replacing a sick heart with a healthy one, complete with technical voiceover commentary. Surgeons were thus given free rein to expand on a mechanistic, scientific approach to issues pertaining to the functioning of the heart, disease, death and donation. Demonstrated by experts and illustrated by a film, this interpretation left little room for the expression of alternative views.
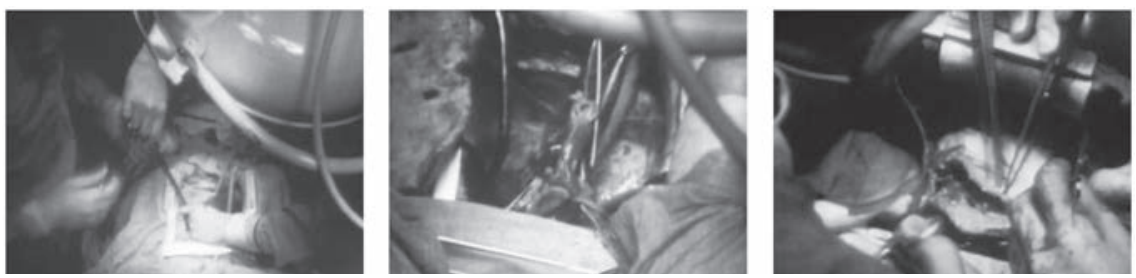

Illustration 5: The show "Restoring life" began with an $8 \mathrm{~min}$ sequence of heart transplant filmed in a didactical way. Each stage from the organ removal to the graft of the replacement heart was punctuated by white board drawings. It is said that the two heart atria of the patient have been preserved to follow Shumway's protocol.

During the same period, other programmes were dedicated to the cultural aspects of transplantation. The show "Fragment of a heart narrative" (Fragments d'un récit du cœur), broadcasted in December 1968, ${ }^{35}$ outlined the symbols attached to the heart in various cultures, with input from scholars in the humanities and representatives of several religions. Yet, the programme ended with a surgeon's opinion: to Pr. Lenègre, "in many ways, the heart enjoys respect, consideration, even though from a physiological standpoint it doesn't deserve it; it is merely a pump. It is only an organ that is tasked with a fairly modest service, not a glorious one; it has to ensure blood circulation". Thus, the discussion was resolved with a one-sided scientific interpretation, arguing the need for organ donation without regard to any other (cultural, emotional, etc.) considerations. Street interviews included in the same programme additionally showed that laypeople were ignorant, or in some cases spread false information about organ retrieval, thereby lending even more credibility to the scientific case for donation.

34 Barrère 1969; Boursaus/Robrini 1969.

35 Chouchan 1968. 
At a time when heart transplants were suspended, it is interesting to see how recipients discussed organ donation on TV. A profile of Father Boulogne was broadcasted on the anniversary of his graft. ${ }^{36} \mathrm{He}$ was again filmed walking up flights of stairs, and his views had not changed significantly. The viewer was however led to understand, by the end of the segment, that the graft had not left his body and soul fully intact. Upon being asked, "if you had to do it all over again, would you?", the patient voiced mixed feelings:

Father Boulogne: "Maybe. If I had known how high the price to pay was, I don't know, as a human, what I'd have done. With the grace of God, maybe. But, I can't answer, because, you know, it would be preposterous on my part, to say yes, straight away. I agreed and so it is, I endure it with all my heart. Would I do it all over again? That is something else".

At the time, Boulogne was the only patient who allowed himself to express his struggles with his experience of the graft, while also defending it. However, this critical testimony on his experience would often be left out of the transplant stories shown on television.

Emmanuel Vitria was less reflexive about transplantation than Father Boulogne, and visibly less affected by adverse effects; he adopted a simple, sincere attitude when he discussed it. He frequently appeared in documentaries or on TV shows from late 1969 onward, after Boulogne's death. He did not campaign for organ donation, but spoke out as a living witness.

Heart transplantation surgery was still covered by TV even though it was no longer being performed. This coverage had educational purposes; cultural - religious, symbolic ${ }^{37}$ - aspects were discussed and the few surviving grafted patients were invited to express themselves. Television continued to support heart transplantation and worked at boosting its scientific and moral legitimacy. Conversely, newspapers no longer dealt with the legitimacy of transplantation; LM, for its part, even became critical on occasion. This difference in coverage may be seen as supporting evidence for our hypothesis that television was the modern ally of heart transplantation in France, owing to its interest and technological specificities.

36 Bourget 1969.

37 Thus, several TV sequences tend to bring the public closer to transplantation and to the patients, such as street interviews highlighting the meanings organ transplantation may have for ordinary people (1 $1^{\text {èr }}$ chaine, 19-09-1969), or a Vitria interview in the football stadium of the Olympique de Marseille (3 ${ }^{\text {ème }}$ chaine, 26-01-1973). Through the process of identification, these images may force in some way an inscription of transplantation in the public's daily life. In addition, the filming of citizens "like others" and the insistence on moral values gave rise to a "two-headed" discourse in which cultural aspects reinforce the authority of scientific arguments. See Chavot/Felt/Masseran 2000. 


\section{3: French Heart Transplants, From the Limelight to the Shadows}

The interruption in heart transplant surgeries, in France and many other countries, ended in 1973. Newspapers was a valuable forum for surgeons who advocated for waiting to resume grafts, including Dubost, who had been affected by the death of his two patients, Joseph Forès and Father Boulogne. In September 1970, at the World Congress of Cardiology in London, where supporters and critics of transplantation squared off, he argued that "[...] heart transplantation should not be pursued further [...] as long as we have nothing better to offer to patients. The tissue typing for both patients who were operated on was very good. Yet, the immunosuppressive treatment they had to go through was very hard on them" (LM 14-09-1970). Le Monde contrasted this stance with the work of US surgeon Shumway, who "indeed has his mind set on proceeding with further operations, and currently remains one of the only surgeons to perform this operation, at the pace of ten surgeries a year". Hence, the press staged a clash between two authorities: while Dubost was the author of the first successful French heart transplant, Shumway enjoyed unquestionable authority as a pioneer and international specialist of heart transplantation. Nonetheless, the newspaper - and the printed press in general - stayed neutral in the "quarrel over transplantation" (SO 1812-73), although Dubost's position was more often reported upon than Shumway's. This editorial preference can be explained by the proximity between the French media and French surgeon.

Newspapers also mentioned the operations and deaths of American transplants, often in news in brief sections. In the early 1970s, TV coverage of heart transplantation was for its part relatively muted. Still, Vitria made regular appearances both in papers and on television, particularly on the anniversaries of his operation. The "vice-dean of heart transplant recipients" 38 was depicted both as a miracle survivor and a man who happily performed everyday tasks (Illustration 6). His longevity helped sustain media interest in heart transplantation, and his recurring appearances showed that journalists did not reject the practice, as was the case in countries such as the UK. ${ }^{39}$

38 This phrase was often used to refer to him in the media.

39 Nathoo 2009. 

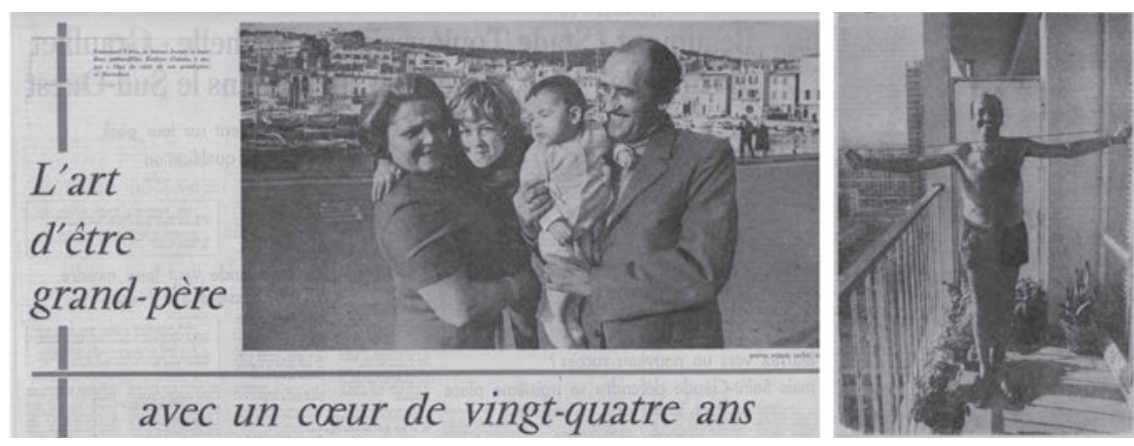

Illustration 6: "The art of being a grandfather with a twenty four year old heart" (SO 3-121972).

\section{The Renaissance of Heart Transplantation in France}

In this climate of defeat, the announcement that Pr. Daniel Guilmet had performed a transplant on Georges Caillez at the Foch Hospital in Suresnes on 24 January 1973 came as a bolt from the blue: the first channel interviewed the surgeon as he left the hospital in his car (1 1 ère chaine, nuit, 24-01-73). The other channels and papers quickly picked up the news. The Caillez surgery heralded a shift in the media coverage and in the relationships between surgeons and the media. First, television was the first to cover the operation; newspapers followed in its footsteps. Secondly, it gave a platform to a staunch advocate and actor of transplantation, at a time when the papers had rather been relaying surgeons' calls to provisionally halt surgeries. That Guilmet adopted TV as a forum was no accident: he was attempting to convince the broadest audience possible, an effort for which television was better suited than any other media.

By 25 January, Guilmet already explained that the operation and postgraft treatments had improved and that he should be performing "one operation each month, as Shumway does". He added that this required "working on the public so that the graft gains acceptance among the families", and on doctors "who take no interest in the graft" ( $2^{2 \mathrm{eme}}$ chaine, 20h, 25-01-73) or "oppose" it (1 ${ }^{\text {ère }}$ chaine, 20h, 25-01-73). In his appearances, Guilmet thus clearly aimed at securing the moral support of the public and of his colleagues. Regarding the public, organ donation had to be supported, as too often relatives vetoed it. Doctors were called upon to support heart transplantation first, to put an end to the quarrel that muddled its image, and secondly, so that brain-dead donors could be identified in all hospital units to make more grafts available. 
Television was particularly well suited to conveying this message. Through image and sound, it showcased alternatively the surgeon, wearing his white coat, a figure of expertise and authority, and Caillez's wife - at the hospital or in her home - who expressed both her hopes and her gratitude. Asked by a journalist about her experience of her husband's graft, she replied: "this was the only solution for me to keep him" (1 ${ }^{\text {ère }}$ chaine, 20h, 25-01-73). Scientific authority and emotion were intertwined on the small screen, in a bid to be as effective as possible in eliciting moral support from a broad audience. Lastly, on the brand new third regional channel, Vitria voiced his enthusiasm about the operation and his support to the graft recipient ( $3^{\mathrm{m}} \mathrm{me}$ chaine, Actualité méditerranée, 26-01-73).

On 4 February 1973, TV used an improved version of a device that had been inaugurated with Vitria; Caillez was filmed live in his sterile room (Illustration 7). This televised presentation of evidence was different from the one that had been proposed for Father Boulogne's surgery. In 1973, the body was exhibited at a time when it had barely recovered, thereby indicating that while this had admittedly been heavy surgery, recovery was swift and the treatment did not have particularly negative effects. The possibility of watching the patient strengthened the evidence: there he was, facing the viewer, in "excellent health", as the journalist put it. This was an advantageous set-up for TV journalists, a feat no other media would have been capable of. This was also of value for the transplanting surgeon, making the result of his operation visible, almost tangible. The respective agendas of the journalists and the doctors were both furthered (1 $1^{\text {ere }}$ chaine, 13h, 04-02-1973).
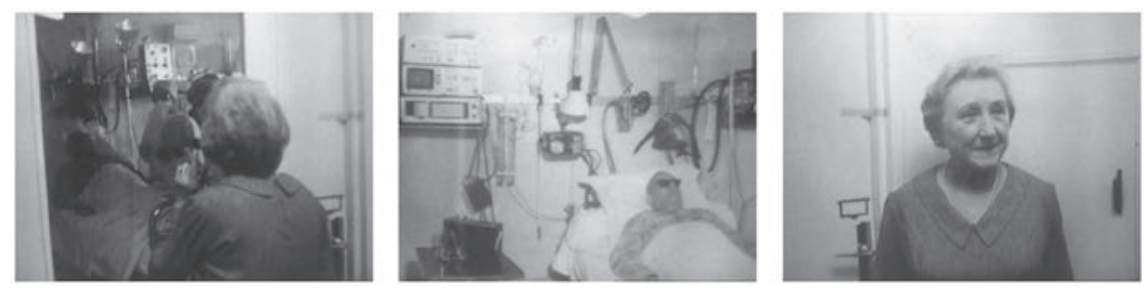

Illustration 7: Live filming of Mr. Caillez in his sterile room during an exchange with his wife (a glass window separates them), followed by the interview of Mrs. Caillez (1 $1^{\text {ere }}$ chaine, 13h, 0402-1973).

Caillez's death on 18 March did not put a stop to heart transplants. Having told the story of his graft, TV now took it upon itself to educate viewers about why it had failed. The first channel showed a fun animated video that explained the mechanism of rejection, depicting the immune system as a regiment of Roman soldiers, defending the body by adopting the tortoise formation. Infectious el- 
ements were little devils, which ended up defeating the soldiers (Illustration 8). The cartoon was shown on several occasions when transplants were performed in 1973. These were opportunities to educate the audience and play down the potentially dramatic consequences of the procedure.
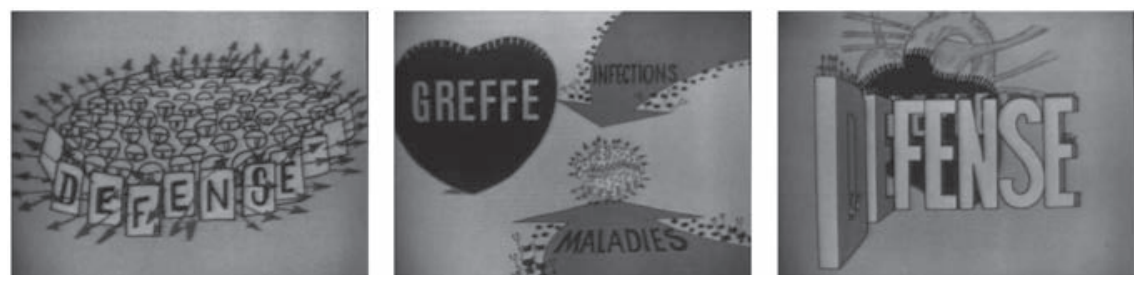

Illustration 8: A science popularization clip explaining the mechanism of rejection (1 $1^{\text {èr }}$ chaine, 20h, 18-03-1973).

On the following day, a press conference was held, during which Guilmet appeared determined to continue to perform transplants, on the grounds that the surgery offered a 30 percent chance of survival to otherwise hopelessly ill patients, citing Shumway's work. Also, he contended, performing multiple surgeries would ultimately improve the procedure, which he called "the last hope for heart patients who feel like they are lost" (1ère chaine, 20h, 19-03-73). The professor came off both as an expert and as a human being, which could help in justifying his practice in the eyes of the audience.

In SO, Guilmet's message appeared to have served its purpose: the journalist seemed to be sold on his TV appearance. Indeed, in a piece entitled "Heart transplants: the pros and the cons" (SO 20-03-1973), the writer took a clear stance in favor of transplantation. The article provided an important forum for Guilmet's opinion: proceeding with further surgeries appeared to be necessary, and it was noted that "even Professor Dubost is in favor of resuming transplants".

Three other surgeries followed. On 3 April, Pr. Pierre Marion attempted another heart transplant at the Lyon hospital; the patient died a few days later. In a televised press conference, Marion declared that the second phase of heart transplantation was now underway (after that of 1968), benefiting from the experience acquired with kidney transplants (1 1 re chaine, Nuit, 3004-73). On 12 May 1973, Guilmet grafted a 26-year-old man. Television was not on the front line as far as coverage went; newspapers followed the story most assiduously. One of the focal points was a medical first: the heart was transported from one hospital to another ${ }^{40}$ which required a technique for

$40 \mathrm{Up}$ to that point, organ retrieval and graft were performed in the same hospital. 
cooling and preservation that was extensively described. The patient survived over a year. The following operation, performed in June again by Guilmet at the Foch Hospital, was also reported upon in a rather sober way; the journalists being satisfied with information coming from Guilmet's press releases. The patient survived for a few months.

Coverage on the first grafts of 1973 emphasized new developments. On a medical level, first, there was a focus on the transportation of the organ, a process that was conducive to dramatizing emergency, which would be an important feature of subsequent graft narratives..$^{41}$ In televisual terms, then, a number of technical innovations were implemented, such as live filming, computer graphics, or interviews with the surgeon on his way out of the operating room. In effect, television covered its own breakthroughs as much as the transplantations: all of these sequences were presented as exclusive and exceptional both in medical and in audiovisual terms. Lastly and crucially, as far as Guilmet's operations were concerned, the surgeon controlled the media coverage, used the media. He left behind from the formal setting of the press conference and went out to talk to reporters. He did not only defend heart transplantation in general, but also and most importantly his own practice of transplantation in particular.

\section{Televised Emotion: Little Céline’s Graft}

By August 1973, France had two new graft recipients who were lived beyond a month after surgery, in addition to Vitria. ${ }^{42}$ Under the circumstances, the media were therefore rather hopeful as they latched onto the case of Guilmet's fourth graft recipient of 1973: Céline Mawoué, a 13-year-old girl with cardiomyopathy, whom they soon took to calling "Little Céline" (la petite Céline). Guilmet sought out and fueled this media coverage, by inviting a reporter from the daily newspaper France-Soir to attend the operation. This time, the surgeon picked newspapers to bring his message across. There was no question of filming the operation, as was done in 1968; this was about telling a story, where the medical message came first. France-Soir ran headlines such as "Heart transplant on a 13-year-old girl - Professor Guilmet's fifth operation"; "How Céline received a 24-year-old man's heart". ${ }^{43}$ A photograph

41 Chavot/Masseran 2012.

42 Guilmet often mentioned the milestones patients had to overcome to increase their chances of surviving the graft: the first ten days, the beginning of the second month, the first two years (after which the risk of rejection no longer exists). The first two months are therefore highly symbolic. See for instance SO 13-05-73.

43 France-Soir 11-08-1973 (document not included in our corpus). 
of a man wearing a white coat carrying a cooler up the hospital stairs took up a quarter of the front page.

However, it was TV that announced the event on 10 August: Guilmet expressed the "great hope" of being able to perform grafts on other ill children. He explained the ins and outs of the operation and boasted the approval of "the vast majority of French cardiologists". Lastly, he announced that as soon as the material conditions to do so were met, he was going to be able to perform one operation each month, noting that there was already a waiting list of about fifteen patients. Television did not just serve as a forum for the surgeon. It offered a complete story, painting a portrait of Little Céline, interviewing her friends and her doctor. It also trotted out another previous graft recipient, Alain Riffaudot, whose functional body it exhibited on this occasion. Riffaudot reported having seen Céline on her way back from the surgery and expressed his enthusiasm about transplantation, which would save "a child". Emphasis was also placed on the fact that Guilmet was the first to resume transplants in Europe (1 1 ère chaine, 20h, 10-08-73).
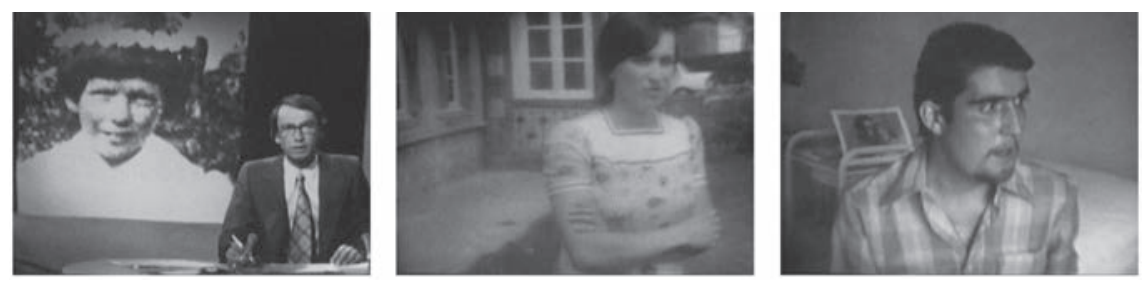

Illustration 9: Little Céline described by her Girl Scout leader and Alain Riffaudeau, grafted three months earlier (1 $1^{\text {ere }}$ chaine, 20h, 10-08-73).

The newspapers did not quite take to this glorification. That the surgeon only invited France-Soir made other journalists angry; they felt they had been discriminated against. Thus, "in a press release published on Friday 10 August, the national union of journalists' trade unions [...] protested in the strongest terms against the fact that news liable to be of interest to French and international public opinion as a whole was given exclusively to a single press organization" (LM 13-08-1973). LM gave a platform to critics of transplantation, such as Pr. Alain Carpentier, who argued that other techniques - like the bypass operation, which was in the process of being developed - would make costly heart transplants irrelevant. In response, Guilmet used the small screen to seek out the public's moral support to transplantation, which he stressed was not a "luxury surgery" (LM 15-08-1973), but a "useful" technique, with the added benefit of relieving social security and one that would allow members of the workforce to remain active. The surgeon also appealed 
to emotion when he claimed that each viewer knew among his relatives and loved ones a cardiac patient for whom "something had to be done" ( $2^{\text {ème }}$ chaine, 20h, 11-08-73).

Having become a media personality, Little Céline died on 7 September 1973. A few days before, she was shown drinking, eating, smiling, getting up and walking in an "exceptional", "deeply moving" TV segment (Illustration 10). Despite her death, television did not question heart transplantation; quite the opposite, in fact, since Guilmet was still and announced that he would continue to perform operations. However, the special relationship that had developed between the surgeon and the media appeared to be frayed.
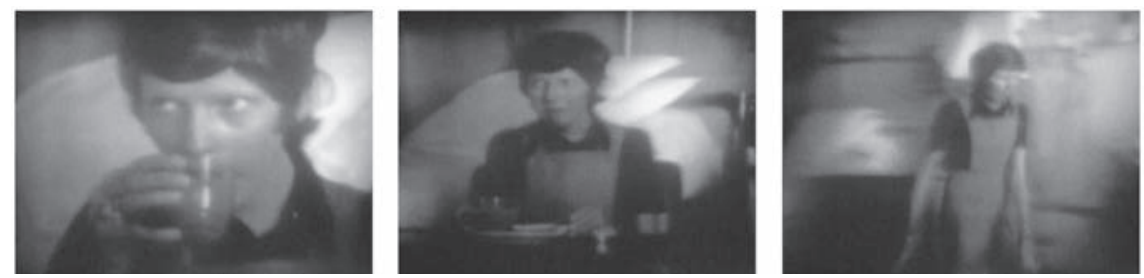

Illustration 10: Filming of Little Céline in her sterile room (1 $1^{\text {èr }}$ chaine, 13h, 03-09-73).

Indeed, in late September, Guilmet performed a new graft, which was covered very minimally on television and in the newspaper. This virtual silence in the media came from the surgeon's own silence; he had announced on TV and in the press that he did not "need personal publicity" (LM 02-10-73). His change of attitude was a response to criticisms. The Minister of Health, Michel Poniatowski had in fact spoken out against the publicity surrounding Little Céline's graft (1ère chaine, 13h, 10-09-73). The French medical council had also issued a statement on the subject, reproduced in LM: "Some surgical procedures [...] were the subject of repeated, inopportune publicity events in newspapers, on radio and on television. The bureau of the French national council wants to make it clear that it condemns such practices [which] place their author in the spotlight" (LM 01-10-73).

The media also lost its appetite for "graft stories". New cases were still reported upon, but the enthusiasm that had surrounded Little Céline's operation was no longer de rigueur. First, newspapers now covered transplantation in far more critical terms. Even SO, which had always voiced its support to heart transplantation, was less passionate, and made room for Dubost, who argued that "as of now, there is no indication for heart transplants" (SO 22-10-73). Secondly, surgeons now adopted a much more low-key, cautious communication strategy, as had been the case in 1968. The heart transplant 
performed by Cabrol in December 1973 at the Broussais Hospital was only made public two days after the surgery. Neither the patient's name nor the circumstances of the operations were mentioned. No press conference was held, even when the patient died shortly thereafter.

Arguably, the craze around Little Céline's graft marked both the peak and the end of an era of alliance between the media and organ transplantation. The storytelling around this operation had every ingredient of a fine televisual narrative, both medical and emotional, centered around a brave surgeon and an ill child. ${ }^{44}$ The media agenda was also ripe for such a story, as this was the fifth French graft of 1973. Additionally, Guilmet had been quite deft at developing relationships with some journalists. There is no doubt that he hoped this coverage would help him secure the public's moral support, which he absolutely needed in order to raise enough funds through donation to open the transplantation center where he planned to operate on one patient each month (LM 13-08-1973; SO 3-10-73).

\section{Conclusion}

In this paper, we have chosen to focus on the 1968-1973 period, which witnessed two peaks in heart transplants and in their media coverage. At least three factors appear to have had an impact on media coverage of transplants. First, we have observed that not all surgeons had the same approach to the media. For instance, Guilmet's 1973 activism stands in sharp contrast with the cautious, reserved attitude adopted by French surgeons in 1968. When surgeons cooperated with the media, or actively sought them out, access to information and increased opportunities boosted coverage.

Secondly, the graft recipient's involvement in the coverage was essential. Blaiberg, Boulogne, Vitria and Marion appeared to cooperate with the media because they had made a choice to promote science after undergoing a transplant. By welcoming the presence of cameras and journalists, they showed in their own words, and by having their body filmed, that they were volunteers for the operation, that it had been successful, and their testimonies alleviated the doubts and criticisms voiced elsewhere in public arenas. Lastly, the media's choice to focus on a given patient hinged on whether their cases lent themselves to effective storytelling, as was the case in the coverage of Vitria, Marion, Caillez, and especially Little Céline.

44 Chavot/Masseran 2012; Cardon/Heurtin 2016. 
Our analysis shows that special relationships between surgeons and journalists developed during these two periods. In 1968, although the French medical board demanded that surgeons limit their communication, they made TV appearances, and showed themselves eager to be interviewed and to contribute to documentaries for state television. At the time, they were involved in the very production process of these segments and programmes; their views prevailed over those of the journalists and their own approach to heart transplantation was conveyed. This involvement allowed them to assert the scientific, therapeutic and moral legitimacy of transplantation.

By 1973, the relationships between surgeons and journalists were radically different. Guilmet, for instance, used the media to counter the scepticism voiced by other doctors and to attempt to ensure the sustainability of transplantation. He teamed up with the media to promote it, showing a clever grasp of media relations. The media, especially television, were forums for him to express his views, and conduits for transplantation stories that appealed to emotion to various degrees. He enlisted journalists in his efforts to gain moral support from the public and the medical community, to sustain and extend the practice. In the latter case, TV was no longer concerned with educating the public, as it had been in 1968; the focus shifted to appealing to emotion through storytelling. Surgeries were no longer filmed, but patients were shown gradually recovering their health and social lives thanks to their new heart. At the same time, newspapers, hindered by far slower production mechanisms than TV, which increasingly relied on live broadcasts, became both a follower and a critic of these new trends. 1973 was ultimately a pivotal year, between the era of the pioneers and the development of a persuasive, strategic communication to promote organ donation.

The media's attitude during that period - especially television - also reflects their role in the reaffirmation of "French greatness" promoted by presidents de Gaulle and Pompidou in the country's post-war boom period known as trente glorieuses. ${ }^{45}$ Television was enlisted in that project, and landmark achievements of medicine were an important part of it. By 1968, the media already partly attributed Barnard's success to France: the French work on tissue compatibility between donor and patient and effective anti-rejection treatments were cited.

All signs thus suggest that the unconditional support of the media helped French surgeons, unlike their counterparts in other countries, to prepare, strengthen and justify their commitment to heart transplantation in 1968 and 1973. Television was then the best media to showcase scientific advances and

45 Vassallo 2005. 
emotionally powerful stories, capitalizing on both registers to affirm the greatness of French surgery. The alliance between journalists and surgeons is likely to have indirectly boosted and directly publicized the French leadership in the field of heart transplantation at the European level, and even globally, at the time.

\section{Bibliography}

Ballarini, Loïc, "Presse locale, un média de diversion", Réseaux 148-149/2 (2008) 405-426

Bauer, Martin, "The medicalization of science news - from the 'rocket-scalpel' to the 'gene-meteorite"', Social Science Information 37 (1998) 731-51

Bonah, Christian/David Cantor/Anja Laukötter (eds.), Health Education Films in the Twentieth Century (Rochester 2018)

Bourdon, Jérôme, Histoire de la télévision sous de Gaulle (Paris 2014)

Cabrol, Christian/Iradj Gandjbakhch/Alain Pavie et al., "Transplantation cardiaque: les raisons du succès", Médecine/Sciences 2 (1986) 81-86

Cardon, Dominique/Jean-Philippe Heurtin, Chorégraphier la générosité. Le Téléthon, le don, la critique (Paris 2016)

Chavot, Philippe/Anne Masseran, "The televisual framing of organ transplantations in France, from the 60s to the 80s", Annales Universitatis Paedagogicae Cracoviensis, Studia ad Didacticam Biologiae Pertinentia 8 (2018) 85-101

Chavot, Philippe/Anne Masseran, "Histoires de greffes: Permanence d'un récit télévisuel", Culture et Musées (2012) 99-128

Chavot, Philippe/Ulrike Felt/Anne Masseran, "Une crise entre savoir et conscience", in Jean-François Collange (ed.), Ethique et transplantation d'organes (Paris 2000) $23-38$

Colombo, Delia/Enrico Amirati, "Cyclosporine in transplantation - A history of converging timelines", Journal of biological regulators and homeostatic agents 25/4 (2011) 493-504

Cooper, David, Christiaan Barnard: The Surgeon Who Dared (London 2017)

Danet, Alina/Rosa M. Medina-Doménech, "A 'tale of two countries': Narratives of hearts, patients and doctors in the Spanish press", Public Understanding of Science 24/6 (2015) 641-657

Esquenazi, Jean-Pierre, L'écriture de l'actualité: pour une sociologie du discours médiatique (Grenoble 2002a)

Esquenazi, Jean-Pierre, "Télévision et espace public sous De Gaulle", Cahiers d'histoire. Revue d'histoire critique 86 (2002b) 49-61

Eveno, Patrick, La presse (Paris 2010)

Guilmet, Daniel, Le cœur qui bat. L'extraordinaire aventure de la chirurgie cardiaque (Paris 1997)

Jeanneney, Jean-Noël, Une histoire des médias des origines à nos jours (Paris 1996)

Joubert, Marina, "1967: Reflections on the first human heart transplant and its impact on medicine, media and society", Public Understanding of Science 27/1 (2018) 110-114 
Martin, Marc, La Presse régionale (Paris 2002)

Kirby, David A., Lab Coats in Hollywood Science, Scientists, and Cinema (London 2011)

Lochard, Guy/Henri Boyer, La communication médiatique (Paris 1998)

Marion, Pierre, Afin que batte le cœur. L'épopée de la chirurgie cardiaque (Lyon 1990)

McCombs, Maxwel E./ Donald L. Shaw, "The Agenda- Setting Function of Mass Media", The Public Opinion Quarterly 36/2 (1972) 176-187

McRae, Donald, Every second counts. The extraordinary race to transplant the first human heart (London, 2006)

Mouillaud, Maurice/Jean-François Têtu, Le Journal Quotidien (Lyon 1989)

Nathoo, Ayesha, Hearts Exposed: Transplants and the Media in 1960s Britain (Basingstoke 2009)

Nelkin, Dorothy, Selling Science: How the Press Covers Science and Technology (New-York 1987)

O’Neill, Robert O., “'Frankenstein to futurism': representations of organ donation and transplantation in popular culture", Transplantation Reviews 20/4 (2006) 222-230

Shapin, Steven/Simon Shaffer, Leviathan and the Air-Pump: Hobbes, Boyle, and the Experimental Life (Princeton 1985)

Soulages, Jean-Claude, Les rhétoriques télévisuelles. Le formatage du réel (Bruxelles/Paris 2007)

Turina, Marko, "Fifty years of heart transplantation", Cardiovascular medicine 21/9 (2018) 209-211

Vassallo, Aude, La télévision sous de Gaulle. Le contrôle gouvernemental de l'information, 1958/1969 (Louvain-la-Neuve 2005)

Veyrat-Masson, Isabelle/Monique Sauvage, Histoire de la télévision française de 1935 à nos jours (Paris 2012)

\section{Filmography}

La chirurgie cardiaque à l'heure de la greffe, directed by Igor Barrère, produced by ORTF (Igor Barrère, Etienne Lalou) $1^{\text {st }}$ channel, 78 minutes, broadcast on 4 February 1969

Redonner la vie, directed by Pierre Boursaus, Claude Robrini, produced by ORTF (Pierre Charpy, Edmond Henry), $1^{\text {st }}$ channel, 60 minutes, broadcast on 24 September 1969

Fragment d'un récit de cœur, directed by Laurent Chouchan, produced by ORTF (Claude Santelli) 2 $2^{\text {nd }}$ channel, 42 minutes, broadcast on 21 December 1968

Chirurgie cardiaque et chirurgie expérimentale, directed by Igor Barrère, Roger Sciandra, produced by ORTF (Igor Barrère, Etienne Lalou) $1^{\text {st }}$ channel, 64 minutes, broadcast on 16 December 1965 


\section{Episodes of television programmes (news broadcasts not included)}

"Le père Bourlogne", Point contrepoint, directed by François Moreuil, produced by ORTF, $2^{\text {ème }}$ chaine, 10 minutes, broadcast on 26 September 1968

"Le père Boulogne: un an après", Panorama, directed by Pierre Bourget, produced by ORTF, lère chaine, 12 minutes, broadcast on 8 May 1969

"Quelques pas avec Blaiberg", Panorama, directed by Christian Bernadac, produced by ORTF, 1ère chaine, 14 minutes, broadcast on 22 March 1968

"Le coeur: Le Cap ces médecins du bout du monde", Panorama, directed by Guilbert Larriaga, produced by ORTF, 1ère chaine, 14 minutes, broadcast on 12 January 1968

"Washkansky n'est pas mort pour rien", Panorama, directed by Pierre Bourget, produced by ORTF, 1ère chaine, 14 minutes, broadcast on 22 December 1967

"Greffe du rein: histoire de deux frères", Cinq colonnes à la une, directed by Igor Barrère, 1ère chaine, 10 minutes, broadcast on 6 November 1959 